\title{
COMMENTS ON ADDITIONAL DINOSAUR SPECIMENS FROM THE JANNER SITE (UPPER TRIASSIC OF THE PARANÁ BASIN), SOUTHERN BRAZIL
}

\author{
RODRIGO TEMP MÜLLER (1) \\ Centro de Apoio à Pesquisa Paleontológica, Universidade Federal de Santa Maria, \\ Rua Maximiliano Vizzotto, 598, 97230-000, São João do Polêsine, RS, Brazil. \\ rodrigotmuller@hotmail.com
}

MAURÍCIO SILVA GARCIA (D)

Laboratório de Paleobiodiversidade Triássica, Departamento de Ecologia e Evolução, Universidade Federal de Santa Maria, Av. Roraima, 1000, 97105-900, Santa Maria, RS, Brazil. maurissauro@mail.ufsm.br

\section{FLÁVIO AUGUSTO PRETTO (D)}

Centro de Apoio à Pesquisa Paleontológica, Universidade Federal de Santa Maria, Rua Maximiliano Vizzotto, 598, 97230-000, São João do Polêsine, RS, Brazil.

\author{
flavio.pretto@ufsm.br
}

\begin{abstract}
The Janner site (Upper Triassic of Southern Brazil) has been intensely explored, yielding constant new findings in recent years. Among these some fragmentary dinosaur specimens still not published were sampled. In this contribution, we describe these specimens, which represent five individuals, in order to increase our understanding on the anatomy of the dinosaurs that compose the paleofauna of the Janner site. The specimen CAPPA/UFSM 0270 is comprised of a series of six articulated presacral vertebrae, plus two isolated vertebrae associated with a right femur. UFRGS-PV-1232-T comprises a sacrum and a left ilium. CAPPA/UFSM 0271 comprises a right humerus that lacks the middle portion of the diaphysis. CAPPA/UFSM 00272 and 2073 are both comprised of an isolated femur each. The fragmentary condition of the materials hampers any less inclusive assignation. However, the morphology of the elements resembles those of coeval dinosaurs. Furthermore, the new specimens increase our knowledge on the morphology of some structures poorly understood from the dinosaurs of Janner site, such as the hindlimb and axial skeleton.
\end{abstract}

Keywords: Hyperodapedon Assemblage Zone, Carnian, Saurischia, Sauropodomorpha, Archosauria, Dinosauria.

RESUMO - O sítio Janner (Triássico Superior do Sul do Brasil) tem sido explorado intensamente, produzindo constantes novos achados nos últimos anos. Dentre estes, restos de dinossauros ainda não publicados foram recuperados. Nesta contribuição nós descrevemos estes espécimes, que totalizam cinco indivíduos, com o objetivo de aumentar o entendimento sobre a anatomia e amostragem de dinossauros que compõem o conteúdo paleofaunístico do sítio Janner. O espécime CAPPA/UFSM 0270 é composto por uma série de seis vértebras pré-sacrais articuladas, além de duas vértebras isoladas e um fêmur direito. UFRGS-PV-1232-T corresponde a um sacro e um ílio esquerdo. CAPPA/ UFSM 0271 compreende um úmero direito que carece de sua diáfise. CAPPA/UFSM 0272 e 0273 compreendem um fêmur isolado cada. A condição fragmentária dos espécimes impede uma atribuição taxonômica menos inclusiva. Porém, a morfologia dos elementos lembra a de dinossauros coevos. Além disso, os novos espécimes aumentam nosso conhecimento sobre a morfologia de estruturas ainda pouco conhecidas de dinossauros do sítio Janner, como o membro anterior e o esqueleto axial.

Palavras-chave: Zona de Associação de Hyperodapedon, Carniano, Saurischia, Sauropodomorpha, Archosauria, Dinosauria.

\section{INTRODUCTION}

The Triassic beds from Brazil yield some of the bestpreserved skeletal remains of the oldest dinosaurs (e.g. Langer et al., 1999; Cabreira et al., 2011; 2016; Müller et al., 2018a; Pacheco et al., 2019; Pretto et al., 2019). Indeed, regarding their age, dinosaurs from Brazil are comparable with those from the
Ischigualasto Formation, Argentina (e.g. Sereno et al., 1993; Martínez et al., 2011; Langer et al., 2018). These findings are helping to build an evolutionary framework on the origin and early radiation of the dinosaurs. In addition, chronostratigraphic investigations dealing with Brazilian and Argentinean dinosaurbearing outcrops are constraining the age that some evolutionary events took place (Martínez et al., 2011; Langer et al., 2018). 
Despite the new findings, dinosaur specimens are still far less sampled than some other tetrapod groups. Actually, dinosaurs probably were rare components on the land ecosystems during the Carnian (Martínez et al., 2013). Consequently, the fossil record of the group is relatively scarce, while other archosauromorphs and synapsids generally are better sampled in the same dinosaur-bearing outcrops. A classic example from Brazil is the fossiliferous content of the Janner site, in the municipality of Agudo, Rio Grande do Sul. The vertebrate paleofauna excavated from this site is considered Late Triassic in age (e.g. Langer et al., 2007; Oliveira et al., 2010; Cabreira et al., 2011), and includes dinosaur records, including new taxa originally collected in this site. The first was the early sauropodomorph Pampadromaeus barberenai Cabreira et al., 2011, which was described based on a partial skeleton of a single individual (ULBRA-PVT016). After that description, two additional specimens (CAPPA/UFSM 0027 and CAPPA/UFSM 0028), each represented by an isolated femur, were referred to $P$. barberenai (Müller et al., 2016, 2019). The other dinosaur from the Janner site is a sauropodomorph as well and was named Bagualosaurus agudoensis Pretto, Langer \& Schultz, 2019, also based in a partial skeleton of a single individual (UFRGS-PV-1099-T). So far, no additional specimens were ascribed to this taxon. In addition to these four aforementioned specimens, there is another described partial skeleton (UFRGS-PV-1240-T, Pretto et al., 2015) that is slightly larger than the holotype of $B$. agudoensis. The general morphology of this specimen resembles that of $B$. agudoensis, but assignment of UFRGSPV-1240-T to that taxon is not robust (Pretto et al., 2019). The published fossil record of dinosaurs from the Janner site, therefore, comprises a total of five specimens. On the other hand, the cynodont genus Exaeretodon Cabreira, 1943, for example, is far more well-sampled, with dozens of specimens from the Janner site and deposited in the paleontological collections from Southern Brazil.

The Janner site has been intensely explored, yielding constant new findings in recent years. Among those findings are several fragmentary dinosaur specimens that are unpublished. In this contribution, we describe these specimens in order to increase our understanding on the anatomy of the dinosaurs that contribute to the paleofauna of the Janner site. Institutional abbreviations. CAPPA/UFSM, Centro de Apoio à Pesquisa Paleontológica da Quarta Colônia, Universidade Federal de Santa Maria, São João do Polêsine, Rio Grande do Sul, Brazil; MCP, Museu de Ciências e Tecnologia, Pontifícia Universidade Católica do Rio Grande do Sul, Porto Alegre, Rio Grande do Sul, Brazil; NMT, National Museum of Tanzania, Dar es Salaam, Tanzania; PVL, Instituto Miguel Lillo, Tucumán, Argentina; PVSJ, División de Paleontologia de Vertebrados del Museo de Ciencias Naturales y Universidad Nacional de San Juan, San Juan, Argentina; ULBRA, Museu de Ciências Naturais, Universidade Luterana do Brasil, Canoas, Rio Grande do Sul, Brazil; UFRGS, Coleção de Paleontologia de Vertebrados, Universidade Federal do Rio Grande do Sul, Porto Alegre,
Rio Grande do Sul, Brazil; UFSM, Coleção de Paleontologia, Laboratório de Estratigrafia e Paleobiologia, Universidade Federal de Santa Maria, Santa Maria, Rio Grande do Sul, Brazil; ZPAL, Institute of Paleobiology of the Polish Academy of Sciences, Warsaw, Poland.

\section{GEOLOGICAL SETTING}

The Janner (= "Várzea do Agudo"; Figure 1) site is located about $2 \mathrm{~km}$ west of the urban center of the municipality of Agudo (531 $\left.17^{\prime} 34.20^{\prime \prime} \mathrm{W}, 29^{\circ} 39^{\prime} 10.89^{\prime \prime} \mathrm{S}\right)$, Rio Grande do Sul State, southern Brazil. It is usually considered late Carnian (Late Triassic) in age (Langer et al., 2007) and included in the Hyperodapedon Assemblage Zone (AZ) (Langer et al., 2007), lower Candelária Sequence (Horn et al., 2014) of the Santa Maria Supersequence of Zerfass et al. (2003) [equivalent to the uppermost portion of the Santa Maria Formation (Andreis et al., 1980)]. As is typical of the Alemoa Member of the Santa Maria Formation (lower Candelária Sequence), its outcrops are composed of ravines of reddish massive to laminated mudstones, but also present yellowish cross-bedded sandstones and sandstones with mudstone interclasts, which are considered part of the Caturrita Formation (upper Candelária Sequence) (Da-Rosa, 2015). Furthermore, the mudstone portion comprises most of the site, being subdivided into proximal and distal floodplain deposits, while the sandstone is regarded as channel and crevasse deposits (Da-Rosa, 2015).

Regarding vertebrate specimens sampled, the Janner site has a moderate diversity of cynodonts and archosauromorphs (Müller et al., 2020). By far, cynodonts are the most abundant faunal element of the Janner paleofauna, mostly represented by the traversodontid Exaeretodon (Oliveira et al., 2007; Liparini et al., 2013; Müller et al., 2015), although the ecteniniid Trucidocynodon riograndensis Oliveira, Soares \& Schultz, 2010 is also present (Oliveira et al., 2010; Stefanello et al., 2018). In term of archosauromorphs, dinosauriforms are the most sampled group in this locality, as previously commented. However, the site has also rhynchosaur remains ascribed to Hyperodapedon Huxley, 1859 (see Langer et al., 2007) and is the type locality of the ornithosuchid Dynamosuchus collisensis Müller et al., 2020. The presence of Hyperodapedon and Exaeretodon places the Janner site in the Hyperodapedon AZ (Langer et al., 2007). The age of this $\mathrm{AZ}$ has been constrained as approximately $233 \mathrm{Ma}$. (Langer et al., 2018). Nevertheless, the overwhelming record of Exaeretodon in comparison to Hyperodapedon could indicate a younger age for the Janner site since the Exaeretodon biozone of the Ischigualasto Formation of Argentina overlaps the layers of the Scaphonyx-Exaeretodon-Herrerasaurus biozone (Martínez et al., 2011). Indeed, the sauropodomorph Bagualosaurus agudoensis is usually regarded as more derived in relation to other sauropodomorphs from the Hyperodapedon AZ (Müller et al., 2018a; Langer et al., 2019; Pretto et al., 2019). However, additional dating is needed for a more reliable stratigraphic framework (for more details on this issue see Müller \& Garcia, 2019). 


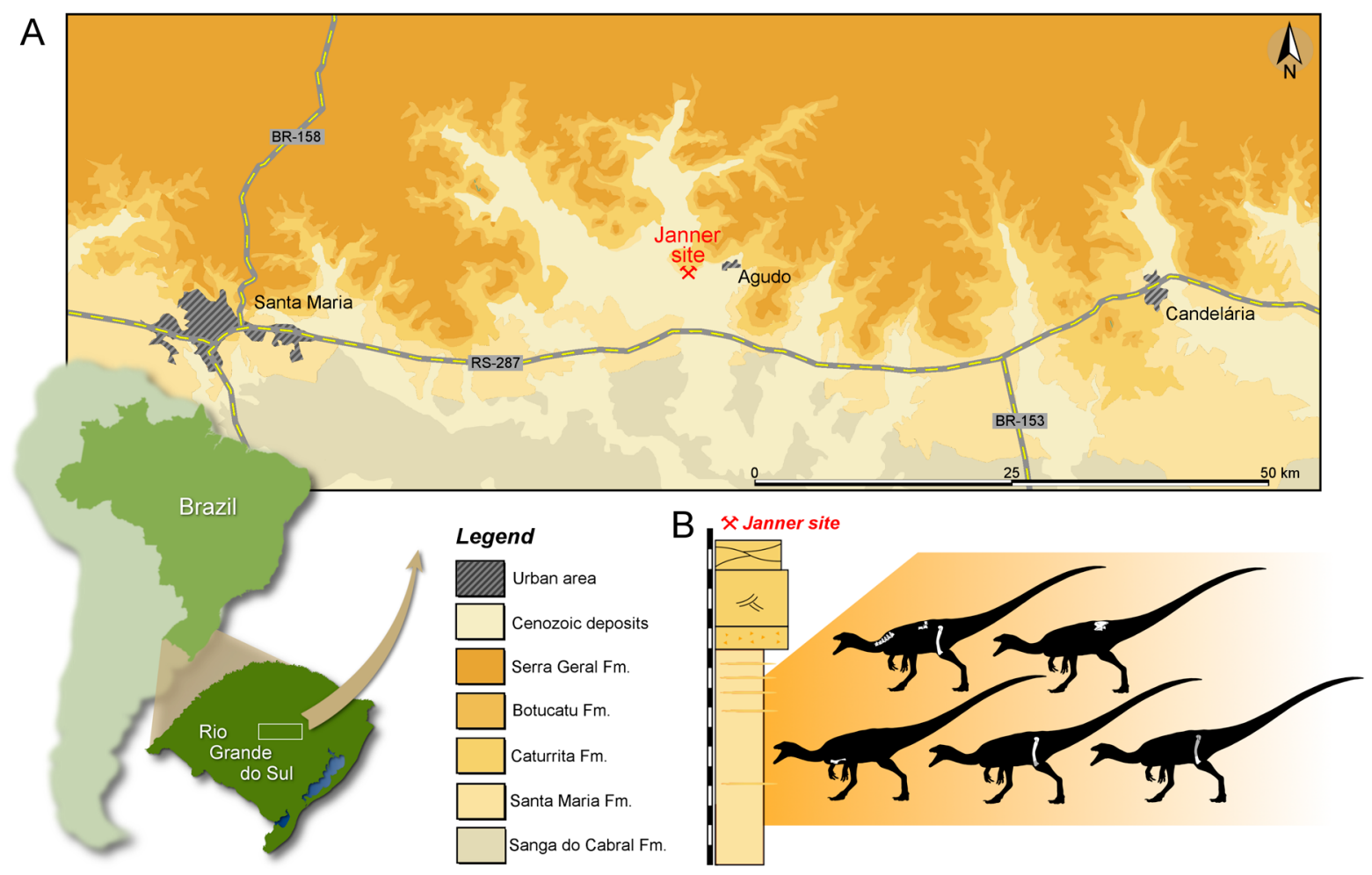

Figure 1. Location and geological context of Janner site. A, location map of the Janner site and the surface distribution of the geologic units in the area (modified from Müller et al., 2020). B, stratigraphic column of the Janner site (modified from Da-Rosa, 2015) depicting the specimens herein studied (silhouettes adapted from the artwork of Márcio L. Castro).

\section{SYSTEMATIC PALEONTOLOGY}

\author{
ARCHOSAURIA Cope, 1869 \\ DINOSAUROMORPHA Benton, 1985 \\ DINOSAURIFORMES Novas, 1992 \\ DINOSAURIA Owen, 1842
}

(Figures 2-7)

Material. CAPPA/UFSM 0270. A series of six articulated presacral vertebrae plus two isolated vertebrae associated with a right femur (Figures 2-3).

Diagnostic traits. The specimen is assigned to Dinosauria due the presence of a concave emargination between the transition from the femoral shaft to the femoral head and the presence of a crest-like and asymmetrical fourth trochanter of the femur. Description and remarks. The six articulated presacral vertebrae (Figure $2 \mathrm{~A}$ ) represent the last two cervical and the first four dorsal vertebrae. The first preserved cervical vertebra lacks the neural arch. The centrum is two times longer than its cranial height, which resembles the condition of Buriolestes schultzi Cabreira et al., 2016 (CAPPA/UFSM 0035). In Macrocollum itaquii Müller, Langer \& Dias-da-Silva, 2018 (CAPPA/UFSM 0001b), which bears a quite elongated neck, the anteroposterior length of the putative equivalent centrum is approximately three times longer than its dorsoventral height. There is a keel running longitudinally along the ventral surface of the centrum. The last cervical vertebra is craniocaudally shorter than the previous vertebra (approximately 0.7 times shorter). Similar to the preceding, it bears a ventral keel, which is poorly developed ventrally. The cranial articular facet of the centrum is more developed ventrally than the caudal facet. The parapophysis lies on the lateral surface of the centrum, close to the cranial articular surface. Caudal to the parapophysis, the centrum bears a shallow fossa that runs craniocaudally reaching its caudal edge. The neural arch is approximately as tall as its respective centrum. The transverse process is lateroventrally directed and connected to the centrum by cranial and caudal centrodiapophyseal laminae. These laminae bound an infradiapophyseal fossa. Due to the preservation of the specimen, the presence of an epipophysis on the dorsal surface of the postzygapophysis is uncertain. The neural spine is low and subrectangular in lateral view. It lacks spine tables or any lateral process and is slightly cranially inclined, as in Saturnalia tupiniquim Langer et al., 1999 (MCP-3845-PV) and distinct from the more cranially expanded spine of Buriolestes schultzi (CAPPA/UFSM 0035).

The centrum of the first dorsal vertebra is approximately as long as the centrum of the last cervical vertebra. A longitudinal keel runs along the ventral surface of the centrum, as in the previous vertebrae. The parapophysis is located on the lateral surface of the centrum, close to the cranial margin. There are three infradiapophyseal fossae at the lateral surface of the neural arch. The neural spine is low and craniocaudally short. The ventral surface is poorly preserved and severely worn and, as a result, it is not possible to assess the presence of a ventral keel. In the subsequent dorsal vertebrae, the 
A
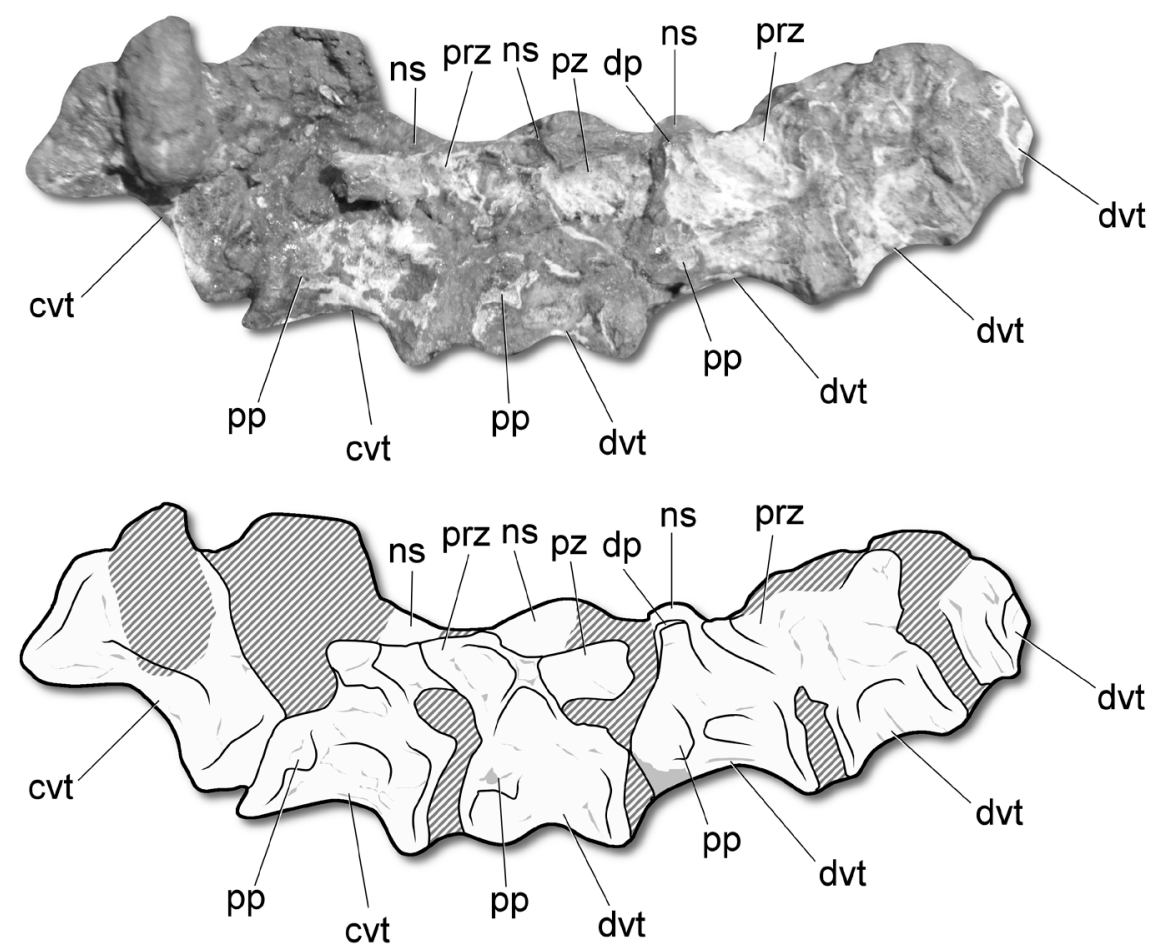

C

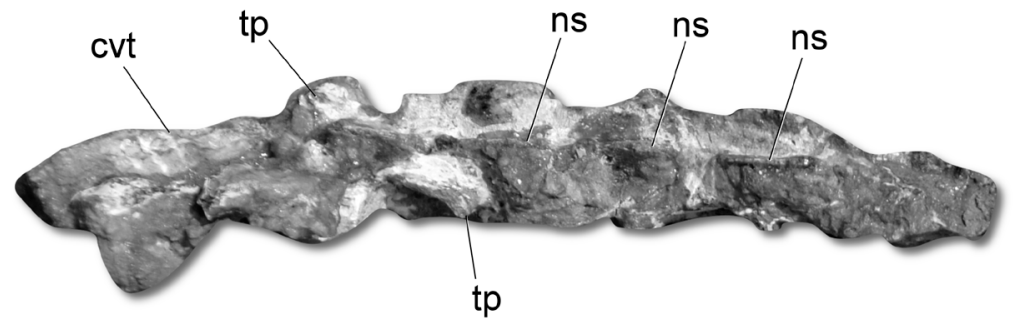

$E$

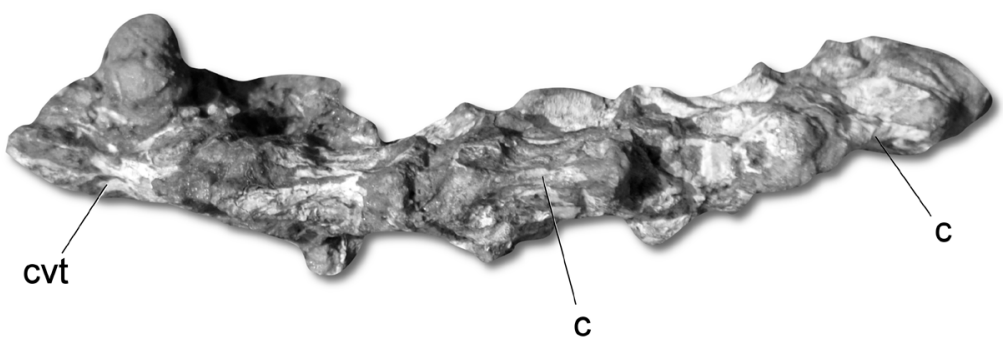

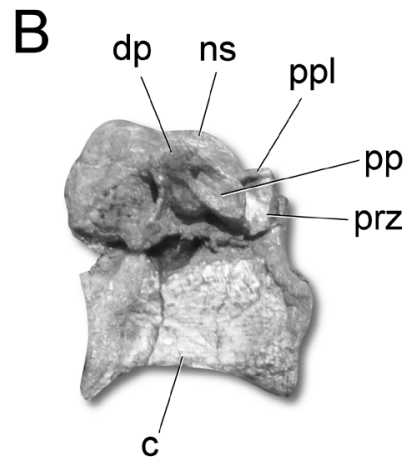
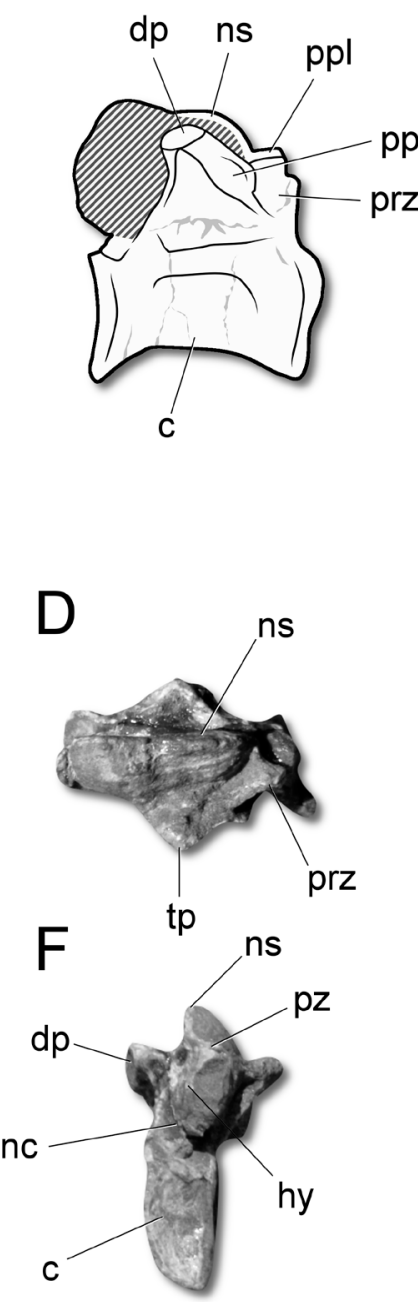

Figure 2. Axial skeleton of CAPPA/UFSM 0270. A, a series of six articulated vertebrae in left lateral view. B, caudal dorsal vertebra in right lateral view. C, a series of six articulated vertebrae in dorsal view. D, caudal dorsal vertebra in dorsal view. E, a series of six articulated vertebrae in ventral view. F, caudal dorsal vertebra in caudal view. Abbreviations: c, centrum; cvt, cervical vertebra; dp, diapophysis; dvt, dorsal vertebra; hy, hyposphene; nc, neural canal; ns, neural spine; pp, parapophysis; ppl, prezygoparapophyseal lamina; prz, prezygapophysis; pz, postzygapophysis; tp, transverse process. Scale bar = 20 mm.

parapophysis is located progressively more dorsally. By the third dorsal vertebra, the parapophysis is almost entirely located on the neural arch. The neural spine of the third dorsal vertebra is craniocaudally longer than the spine of the previous vertebrae. There is no ventral keel in the centrum of the third dorsal vertebra.
One of the two isolated vertebrae preserves the centrum and the neural arch (Figure 2B). This vertebra belongs to the caudal portion of the dorsal series. This identification relies on the position of the parapophysis, which is close to the diapophysis. The craniocaudal length of the centrum is approximately 1.85 times longer than is dorsoventral 

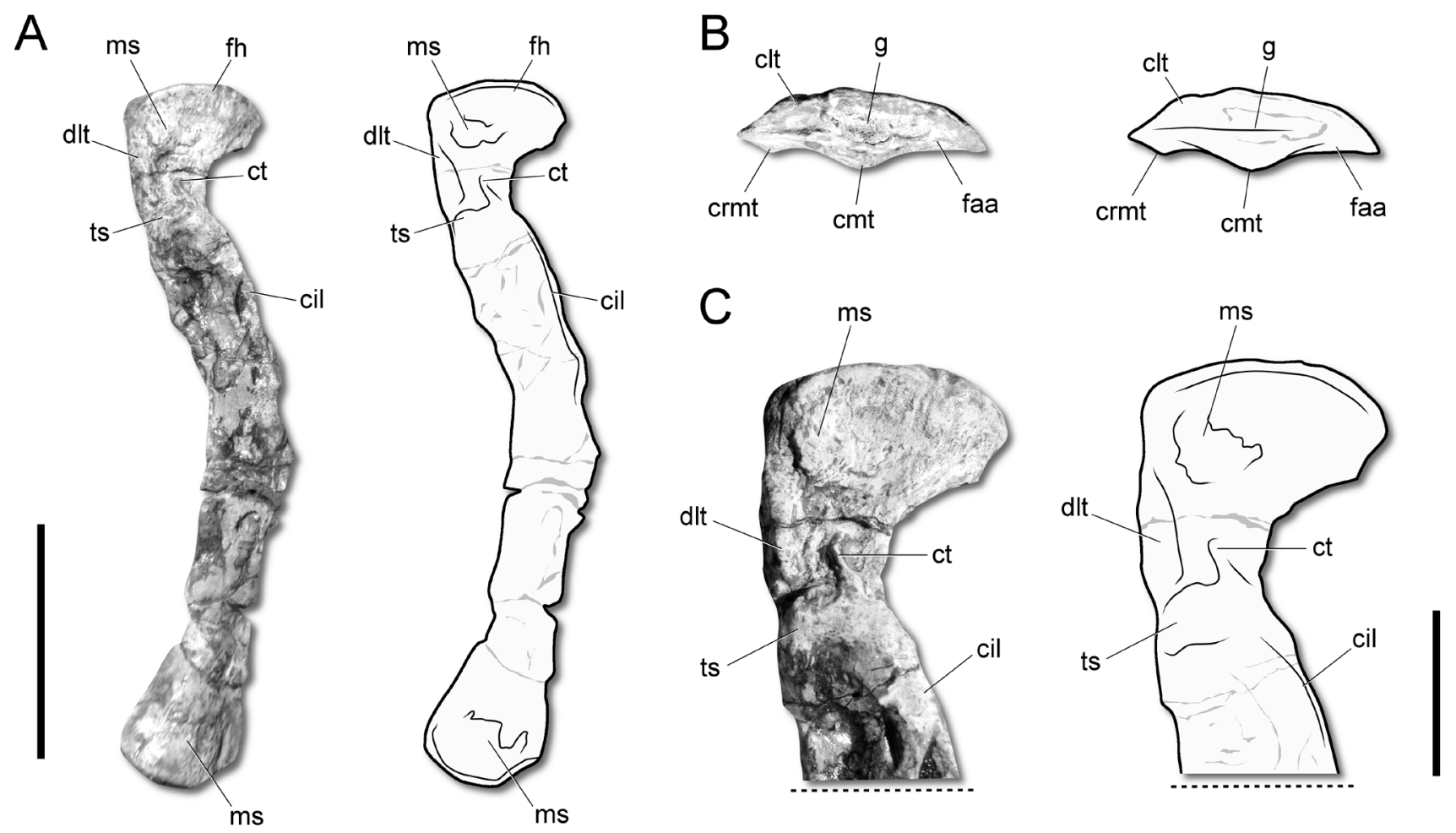

Figure 3. Right femur of CAPPA/UFSM 0270. A, craniolateral view. B, proximal view. C, detail of the proximal portion in craniolateral view. Abbreviations: cil, cranial intermuscular line; clt, craniolateral tuber; cmt caudomedial tuber; crmt, craniomedial tuber; ct, cranial trochanter; dlt, dorsolateral trochanter; faa, facies articularis antitrochanterica; fh, femoral head; g, groove; ms, muscle scar; ts, trochanteric shelf. Scale bars: $\mathrm{A}=50 \mathrm{~mm}$; B-C = $20 \mathrm{~mm}$.

height. This condition differs from herrerasaurids, which bear craniocaudally short dorsal centra (e.g. Herrerasaurus ischigualastensis Reig, 1963 - PVL 2566; Staurikosaurus pricei Colbert, 1970 - MCZ 1669; Sanjuansaurus gordilloi Alcober \& Martinez, 2010 - PVSJ 605; Novas, 1993; Bittencourt \& Kellner, 2009; Alcober \& Martínez, 2010). There are two infradiapophyseal fossa below the transverse process. However, there is an additional fossa cranial to the parapophysis, which is roofed by a prezygoparapophyseal lamina. This lamina represents the prezygodiapophyseal lamina of the previous vertebrae. However, the dorsal displacement of the parapophysis interrupts the connection between the prezygapophysis and the diapophysis. The medial portion of the ventral surface of the postzygapophysis projects ventrally to form a dorsoventrally short and sheet-like hyposphene accessory articulation, which is usually present in saurischian dinosaurs (Nesbitt, 2011). The base of the neural spine is approximately as long as the craniocaudal length of the neural arch (excluding the pre- and postzygapophyses). The distal portion of the spine is missing. The other isolated vertebra is composed of an isolated centrum that lacks parapophyses. Therefore, it probably belongs to a mid/caudal dorsal vertebra or a caudal vertebra. The size and proportions of the element resemble those of the isolated dorsal vertebra previous mentioned. The centrum is constricted at the mid length, lacks any keel, and bears a lateral fossa.

The femur (Figure 3 ) is approximately $144 \mathrm{~mm}$ in length and diagenetically altered in its transverse dimension by sedimentary compression (minimum circumference of the shaft approximately $42 \mathrm{~mm}$ ). The bone is sigmoid (Figure 3A), with a slender shaft and expanded extremities. The maximum lateromedially width of the femoral head is approximately $29.5 \mathrm{~mm}$. There is a shallow transverse groove running on the proximal surface (Figure 3B). The craniolateral margin of the proximal end is convex, while the opposite side bears two concavities formed by the presence of the craniomedial and caudomedial tubera. These are subequal in size. The facies articularis antitrochanterica is ventrally directed, distinct from the condition of silesaurids (Nesbitt, 2011) where this surface is elevated in comparison. The greater trochanter is angled and the transition between the femoral head and the shaft is marked by a ventral concavity, a diagnostic trait of dinosaurs (Nesbitt et al., 2010). The dorsolateral trochanter forms a raised process with smooth margins. In addition, there is a raised muscle scar (Figure 3C) slightly dorsal to this trochanter, which also occurs in some dinosauriforms, such as Silesaurus opolensis Dzik, 2003 (ZPAL AbIII/361/21 - Piechowski et al., 2014), Asilisaurus kongwe Nesbitt et al., 2010 (NMT RB159Griffin \& Nesbitt, 2016), Buriolestes schultzi (CAPPA/UFSM 0035 - Müller et al., 2018a), and Gnathovorax cabreirai Pacheco et al., 2019 (CAPPA/UFSM 0009 - Pacheco et al., 2019). Lateral to the dorsolateral trochanter runs a sharp longitudinal ridge that represents the cranial trochanter. This trochanter differs from several theropods and ornithischians by the shape of the proximal end, which connects smoothly to the femoral shaft. The distal end of this trochanter is connected to a pronounced, transversely oriented ridge. This structure represents the trochanteric shelf and is absent in post-Carnian 

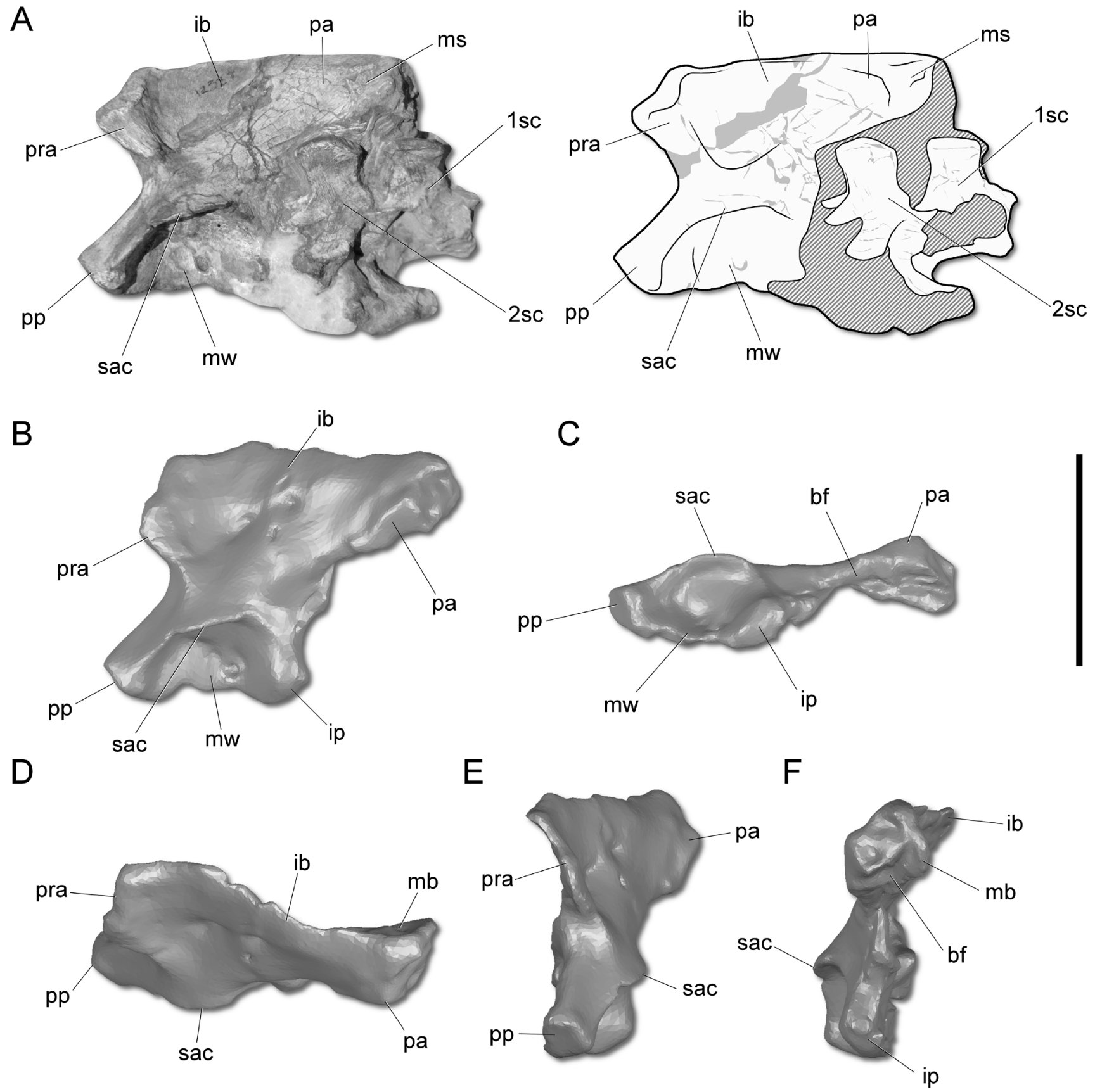

Figure 4. Sacrum of UFRGS-PV-1232-T. A, left ilium in lateral view and sacral vertebrae in right lateral view. B, three-dimensional rendering of the left ilium in lateral view. $\mathbf{C}$, three-dimensional rendering of the left ilium in ventral view. D, three-dimensional rendering of the left ilium in dorsal view. $\mathbf{E}$, threedimensional rendering of the left ilium in cranial view. $\mathbf{F}$, three-dimensional rendering of the left ilium in caudal view. Abbreviations: 1sc, first primordial sacral vertebra; $\mathbf{2 s c}$, second primordial sacral vertebra; bf, brevis fossa; ib, iliac blade; ip, ischiadic peduncle; $\mathbf{m b}$, medial blade; ms, muscle scar; $\mathbf{m w}$, medial wall; pa, postacebatular ala; pp, pubic peduncle; pra, preacetabular ala; sac, supracetabular crest. Note that the sacral vertebrae are not articulated with the ilium and rotated $180^{\circ}$. Scale bar $=50 \mathrm{~mm}$.

sauropodomorphs, like Macrocollum itaquii (CAPPA/UFSM 0001b) and Coloradisaurus brevis (Bonaparte, 1978) (PVL 5904). However, the trochanteric shelf is a typical trait of Carnian dinosaurs, recognized in herrerasaurids (Novas, 1993; Pacheco et al., 2019), sauropodomorphs (Ezcurra, 2010; Cabreira et al., 2016; Pretto et al., 2019), and putative theropods (Martínez et al., 2011). A sharp longitudinal ridge that corresponds to the cranial intermuscular line runs ventral to the craniolateral corner of the trochanteric shelf. The fourth trochanter is crest-like and asymmetrical, with the distal margin forming a steeper angle to the shaft. The medial surface of that trochanter bears a fossa that probably represents the insertion point of the musculus caudofemoralis longus (see Langer, 2003).

On the craniolateral surface of the distal portion there is a point densely marked by muscle scars (Figure 3A). A 


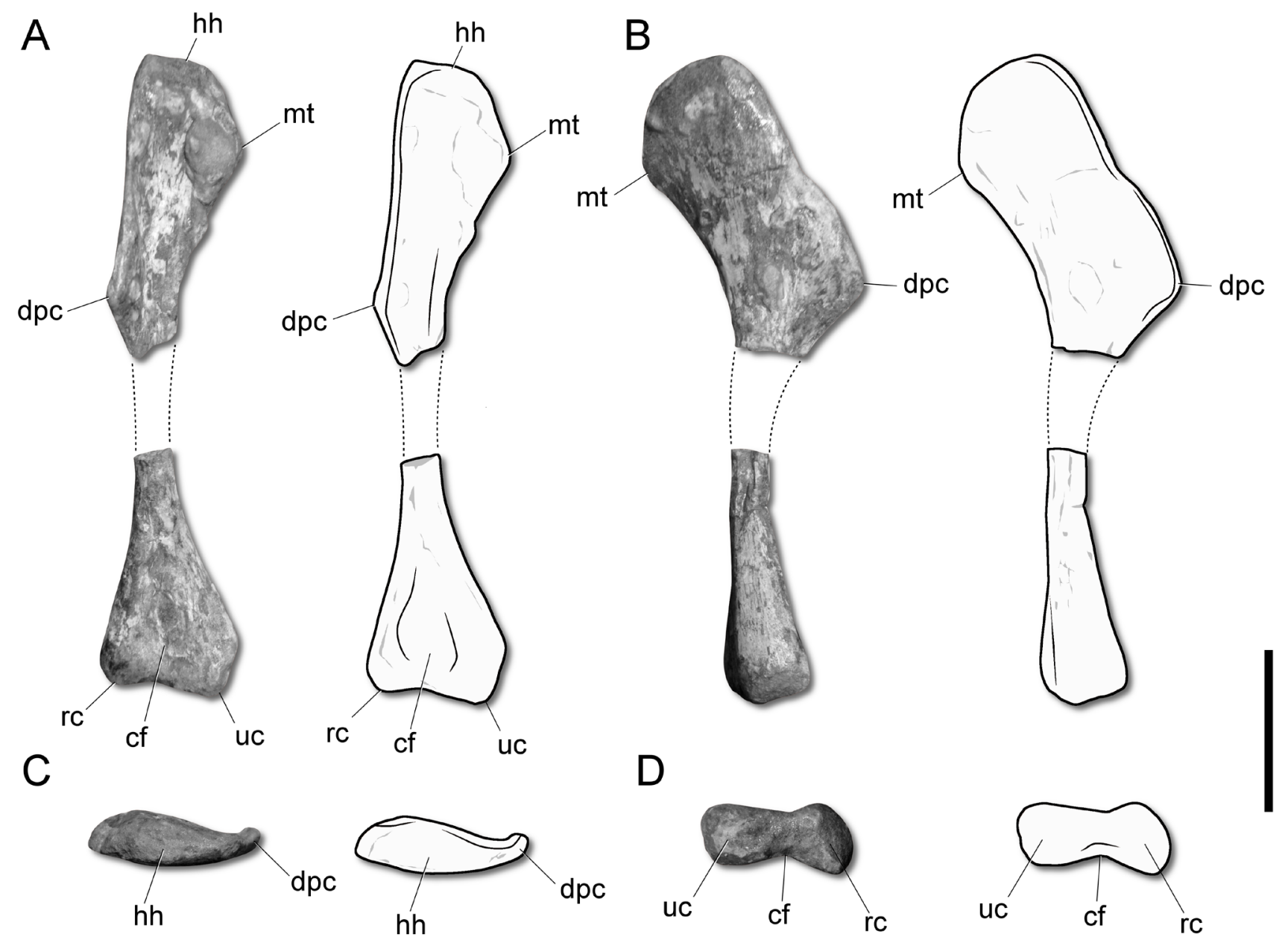

Figure 5. Right humerus of CAPPA/UFSM 0271. A, cranial view. B, lateral view. C, proximal view. D, distal view. Abbreviations: cf, cuboid fossa; dpc, deltopectoral crest; hh, humeral head; $\mathbf{m t}$, medial tuberosity; $\mathbf{r c}$, radial condyle; uc, ulnar condyle. Scale bar $=20 \mathrm{~mm}$.

similar condition was also reported for other coeval dinosaurs, like Saturnalia tupiniquim (MCP 3944-PV - Langer, 2003) Buriolestes schultzi (CAPPA/UFSM 0035 - Müller et al., 2018a), and Pampadromaeus barberenai Cabreira et al., 2011 (CAPPA/UFSM 0027 - Müller et al., 2016). The popliteal surface occupies approximately $20 \%$ of the total length of the bone, distinct from several silesaurids (e.g. Silesaurus opolensis, Sacisaurus agudoensis Ferigolo \& Langer, 2006), which bear proximodistally longer fossae (Nesbitt et al., 2010). In distal view, the fossa is wide and U-shaped. The distal articular surface is strongly affected by sedimentary compression. Therefore, it is hard to discern the crista tibiofibularis from the lateral condyle. Nevertheless, both are clearly smaller than the medial condyle. There is a groove between the craniomedial and the caudolateral portions of the distal articular surface.

Material. UFRGS-PV-1232-T. A sacrum and a left ilium (Figure 4).

Diagnostic traits. The specimen is assigned to Dinosauria due the presence of a brevis shelf, a ventrally oriented brevis fossa, and the straight to slightly convex ventral margin of the acetabular wall of the ilium.

Description and remarks. The sacrum preserves the two primordial sacral vertebrae and their respective ribs (Figure 4A). The centrum of the first sacral vertebra is elongated. The cranial articular surface is concave and crescent shaped in cranial view. The caudal articular surface is articulated against the cranial articular surface of the second sacral vertebra. However, both elements are not co-ossified. The size of the centrum of the second sacral vertebra is uncertain as it is obscured by a dense layer of sediment. The prezygapophysis of the first sacral vertebra is cranially short and does not extend past the level of the cranial margin of its centrum. The transverse process roofs partially the first sacral rib. The ventral portion of the first sacral rib is not preserved. However, the morphology of the preserved parts that it was " $\mathrm{C}$ "-shaped in lateral view, matching the morphology of coeval saurischians, like Pampadromaeus barberenai (ULBRA-PVT016), Saturnalia tupiniquim (MCP 3944-PV), and Bagualosaurus agudoensis (UFRGS-PV1099-T). The transverse process of the second sacral vertebra 

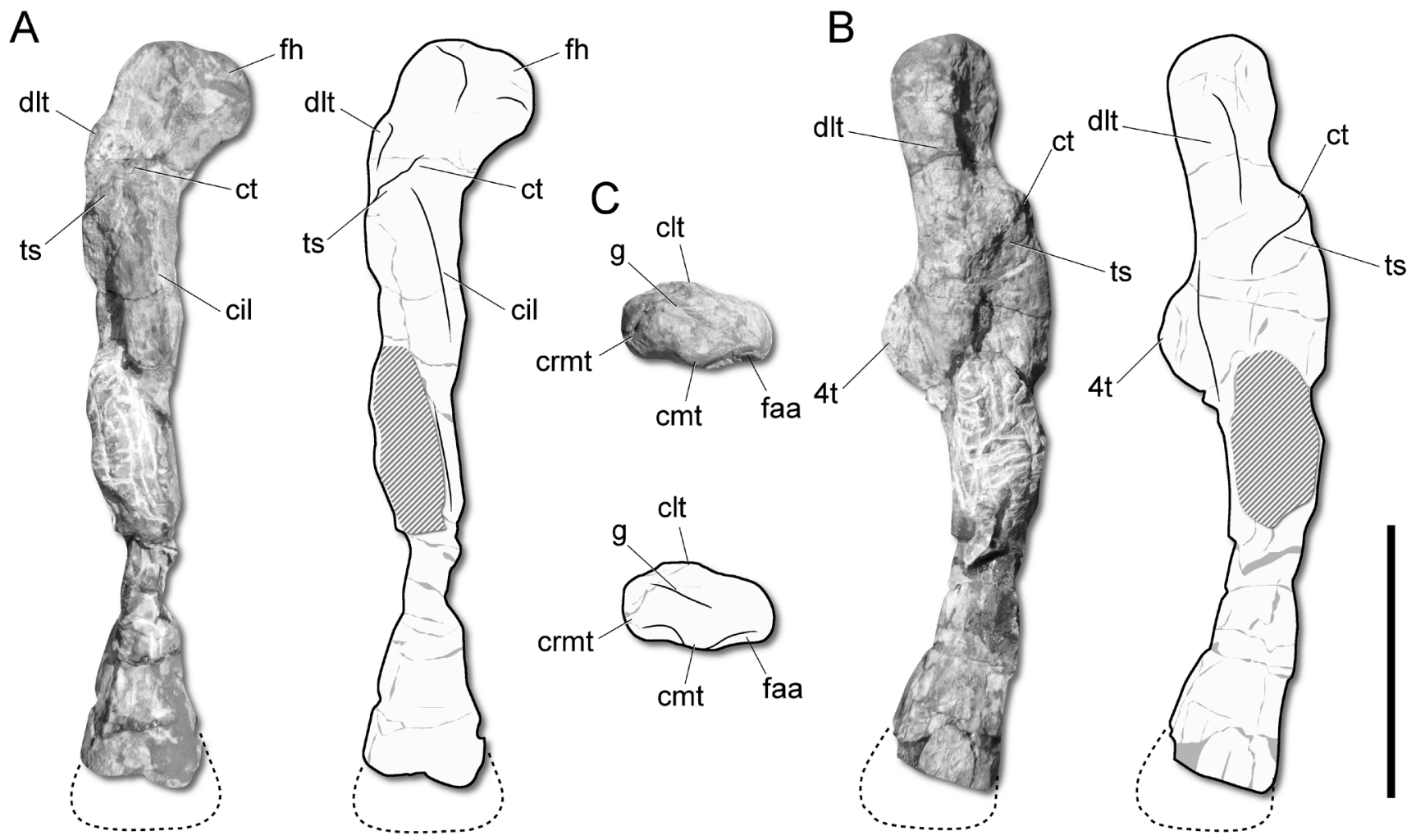

Figure 6. Right femur of CAPPA/UFSM 0272. A, cranial view. B, lateral view. C, proximal view. Abbreviations: 4t, fourth trochanter; cil, cranial intermuscular line; clt, craniolateral tuber; cmt caudomedial tuber; crmt, craniomedial tuber; ct, cranial trochanter; dlt, dorsolateral trochanter; faa, facies articularis antitrochanterica; fh, femoral head; $\mathbf{g}$, groove; ts, trochanteric shelf. Scale bar $=50 \mathrm{~mm}$.

is caudolaterally directed, while its rib runs cranioventrally, resulting in an "S" shape in lateral view. The putative ventral contact with the first sacral rib is not visible as the caudal end of the first sacral rib is not preserved. On the other hand, a dorsal contact between the elements is clearly absent in the specimen. This condition resembles the morphology of coeval sauropodomorphs (e.g. Pampadromaeus barberenai - ULBRA-PVT016; Buriolestes schultzi - CAPPA/UFSM 0035), whereas in Herrerasaurus ischigualastensis (PVL 2566) a caudal expansion of the transverse process of the first sacral vertebra attaches against a cranial expansion of the transverse process of the second element (Novas, 1993). The neural spines of both sacral vertebrae are subequal in size. In contrast, in Bagualosaurus agudoensis (UFRGS-PV-1099-T) the neural spine of the first sacral vertebra is craniocaudally shorter than the spine of the second element. This specimen is distinct from Herrerasaurus ischigualastensis (PVL 2566), because UFRGS-PV-1232-T lacks spine tables. On the other hand, the specimen bears gently striated expansions on the distal tip of the neural spines, which resemble the holotype (ULBRA-PVT016) of Pampadromaeus bareberenai (Langer et al., 2019).

The ilium is $83 \mathrm{~mm}$ in length (Figure 4). The cranial margin of the preacetabular ala does not exceed the cranial margin of the pubic peduncle. Resembling the holotype (ULBRA-PVT280) of Buriolestes schultzi, the tip of the preacetabular process is sub-rectangular and tall. On the other hand, the same structure is pointed to sub-triangular in the post-Carnian sauropodomorphs, Macrocollum itaquii (CAPPA/UFSM 0001b) and Saturnalia tupiniquim (MCP 3946-PV). Moreover, there is a raised scar (Figure 4A) that resembles those present in the holotype (ULBRA-PVT280) of Buriolestes schultzi, Saturnalia tupiniquim (MCP 3945-PV), and a putative saturnaliin from Brazil (CAPPA/UFSM $0200-$ Garcia et al., 2019). However, in the indeterminate saturnaliin, the raised scar is mostly horizontally oriented and more rugous, while in UFRGS-PV-1232-T the scar is more vertical and less rough. In addition, a specimen referred to Buriolestes schultzi (CAPPA/UFSM 0035) also has a scar, but it does not form a raised process, similar to a condition observed in the holotype of Pampadromaeus barberenai (ULBRA-PVT016; Langer et al., 2019). The scar of UFRGS-PV-1232-T extends longitudinally along the dorsal surface of the iliac blade, but it does not form a raised process. Nevertheless, at the caudal portion of the postacetabular ala, the scars becomes a raised process again, resembling the condition of Buriolestes schultzi (ULBRA-PVT280, CAPPA/UFSM 0035), Chromogisaurus novasi Ezcurra, 2010 (PVSJ 845), Saturnalia tupiniquim (MCP 3944-PV, 3945-PV), and CAPPA/UFSM 0200 (Langer, 2003; Ezcurra, 2010; Müller et al., 2018a; Garcia et al., 2019).

The postacetabular ala is more developed than the preacetabular ala (Figure 4B), exceeding the ischiadic 

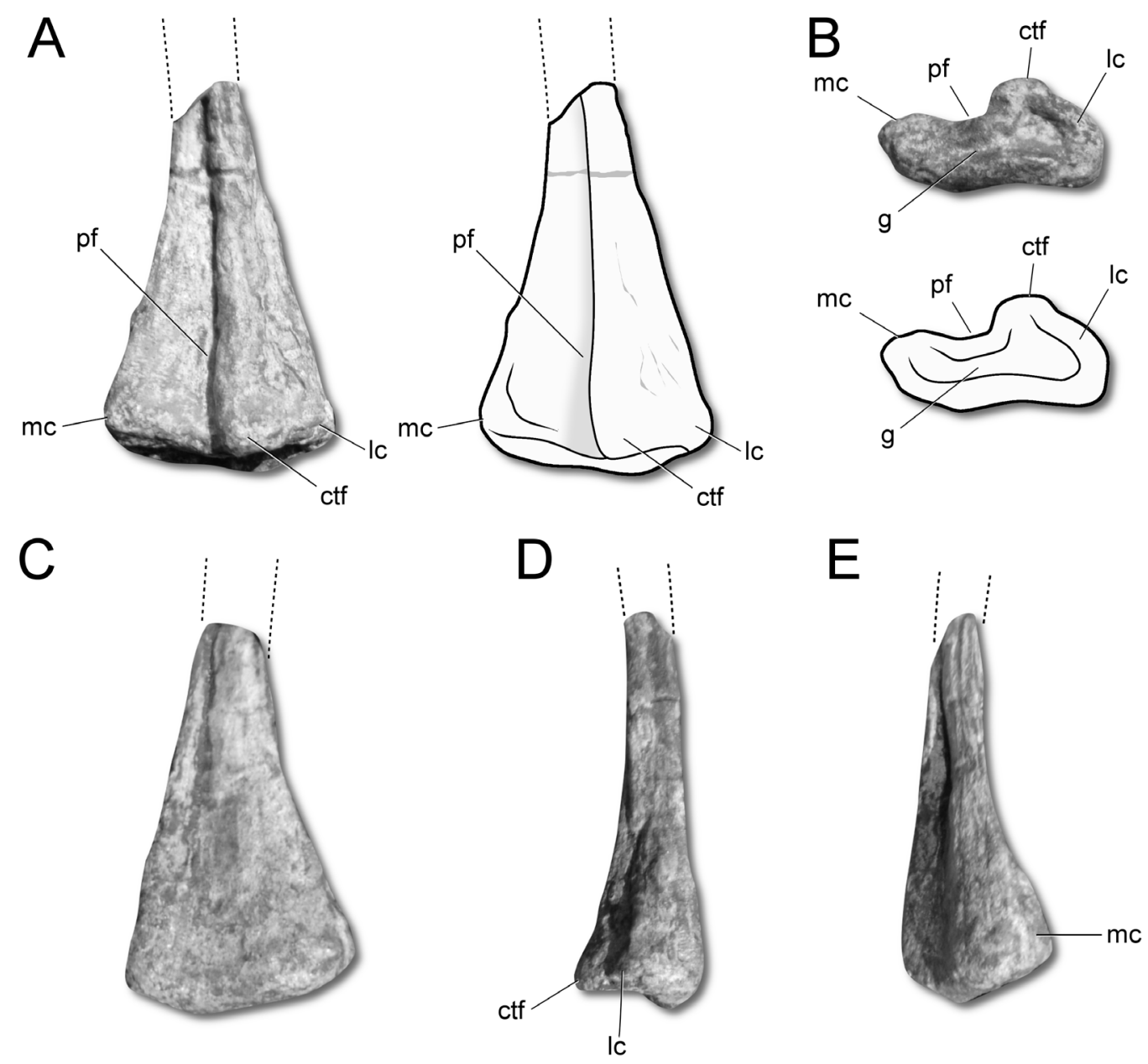

Figure 7. Right femur of CAPPA/UFSM 0273. A, caudal view. B, distal view. C, cranial view. D, lateral view. E, medial view. Abbreviations: ctf, crista tibiofibularis; $\mathbf{g}$, groove; lc, lateral condyle; $\mathbf{m c}$, medial condyle; pf, popliteal fossa. Scale bar $=20 \mathrm{~mm}$.

peduncle. In herrerasaurids such as Herrerasaurus ischigualastensis (PVL 2566), Gnathovorax cabreirai (CAPPA/UFSM 0009), and especially Staurikosaurus pricei (MCZ 1669) the postacetabular process is considerable shorter. As typical of dinosaurs, there is a brevis fossa on the ventral surface of the postacetabular ala (Figure 4C). The iliac blade is dorsoventrally larger than the dorsoventral height of the iliac acetabulum. The dorsal margin of the iliac blade is almost straight along its entire length. The supracetabular crest runs along the pubic peduncle and forms the roof of the acetabulum. However, the cranial tip of the crest does not reach the cranial end of the pubic peduncle and also merges caudally with the ilium distant from the cranial portion of the brevis shelf. Moreover, the crest is well-developed laterally and slightly ventrally oriented. The medial wall of the acetabulum reaches the ventral margin of the bone, almost completely closing the acetabulum, a usual condition in Carnian dinosaurs, except for herrerasaurids (e.g. Herrerasaurus ischigualastensis - PVL 2566; Staurikosaurus pricei-MCZ 1669; Gnathovorax cabreirai-CAPPA/USFM 0009).
Material. CAPPA/UFSM 0271. A right humerus that lacks the middle portion of the diaphysis (Figure 5).

Diagnostic traits. The specimen is assigned to Dinosauria due the presence of a dorsoventrally well developed and subrectangular deltopectoral crest of the humerus.

Description and remarks. The bone is separated in two portions. The proximal portion is approximately $42.5 \mathrm{~mm}$ in length and encompasses the entire deltopectoral crest. The proximal articular surface is straight to gently convex. There is no caudal tuberosity in the head, contrasting with many dinosaurs like Buriolestes schultzi (ULBRAPVT280), Herrerasaurus ischigualastensis (PVSJ 373), and Macrocollum itaquii (CAPPA/UFSM 0001b). The medial tuberosity is ventrally directed, while in Herrerasaurus ischigualastensis (PVSJ 373) it forms a dorsally projected, finger-shaped process (Sereno et al., 1993). Moreover, the transition between the proximal articular surface and the medial tuberosity is smooth, while in Buriolestes schultzi (ULBRA-PVT280) and Herrerasaurus ischigualastensis (PVSJ 373) there is a marked gap. The condition of the specimen resembles post-Carnian sauropodomorphs, like 
Unaysaurus tolentinoi Leal et al., 2004 (UFSM 11069) and Adeopapposaurus mognai Martinez, 2009 (PVSJ 610). The deltopectoral crest is well developed, as typical for dinosaurs. The structure is subrectangular and bears a faint concavity in the proximal portion, at the contact with the main body of the bone. In cranial view the crest is straight, rather than strongly sinuous as in some sauropodomorphs like Coloradisaurus brevis (PVL 5904 - Apaldetti et al., 2013). The lateral surface of the crest lacks a longitudinally oriented ridge, which is present in Buriolestes schultzi (ULBRA-PVT280), Saturnalia tupiniquim (MCP 3844-PV) and Unaysaurus tolentinoi (UFSM 11069).

The distal preserved portion of the humerus is approximately $37 \mathrm{~mm}$ in length. As preserved, the shaft is remarkably slender ( 5 to $6 \mathrm{~mm}$ wide and minimum circumference of the shaft approximately $17 \mathrm{~mm}$ ), while the distal end is transversely expanded (maximum width is approximately $19.2 \mathrm{~mm}$ ). The cranial surface of the distal portion is gently concave. The radial condyle is more developed cranially than the ulnar condyle. In contrast, the latter is more developed distally, which resembles Buriolestes schultzi (ULBRA-PVT280) and Saturnalia tupiniquim (MCP 3844-PV). Both condyles are separated by a shallow cuboid fossa. Distinct from Buriolestes schultzi (ULBRA-PVT280) and Herrerasaurus ischigualastensis (PVSJ 373), the specimen lacks a rugose swelled crest on the entepicondylar surface.

Material. CAPPA/UFSM 0272. A partial right femur that lacks the distal articular surface (Figure 6).

Diagnostic traits. The specimen is assigned to Dinosauria due the presence of a concave emargination between the transition from the femoral shaft to the femoral head.

Description and remarks. The preserved length is approximately $130 \mathrm{~mm}$ and the minimum circumference of the shaft is approximately $39 \mathrm{~mm}$. The bone is sigmoid as typical for dinosaurs, and the femoral head is medially projected, but this is accentuated by taphonomic distortion. The maximum length of the proximal end is approximately $27 \mathrm{~mm}$. A transverse groove lies on the proximal articular surface, and a tuber marks its craniolateral margin. There are two additional tubers on the caudal margin, one craniomedial and the other caudomedial. Both tubers are subequal in size and are separated by a sulcus for the ligament of the femoral head. In contrast to the morphology observed here, the caudomedial tuber is generally expanded in nondinosaur dinosauriforms (Novas, 1996). The facies articularis antitrochanterica is ventrally oriented. The dorsolateral trochanter forms a sharp raised process and does not lie on the cranial surface of the femoral head. The cranial trochanter is proximodistally oriented and is connected to a trochanteric shelf that reaches the caudomedial margin of the bone. An intermuscular line runs longitudinally from the distal portion of the cranial trochanter. The fourth trochanter is symmetrical and crest-like, with both proximal and distal margins forming low angles with the shaft. This condition differs from several coeval dinosaurs (e.g. Buriolestes schultzi, CAPPA/UFSM 0035; Pampadromaeus barberenai, CAPPA/UFSM 0027; Saturnalia tupiniquim, MCP3944-PV) where the distal margin of the trochanter forms a steeper angle to the shaft, resulting in an asymmetrical trochanter. However, a symmetrical fourth trochanter is recognized in non-dinosaur dinosauromorphs (e.g. Ixalerpeton polesinensis Cabreira et al., 2016, Dromomeron gregorii Nesbitt et al., 2009, Sacisaurus agudoensis), Staurikosaurus pricei (MCZ 1669), and theropods [e.g. Coelophysis bauri (Cope, 1887), Liliensternus liliensterni (Huene, 1934), Dilophosaurus wetherilli (Welles, 1954) - Nesbitt, 2011] as well as in one of the femora of Bagualosaurus agudoensis, though Pretto et al. (2019) argued that its morphology represents overpreparation. In addition, this trochanter is proportionally proximodistally shorter than that of CAPPA/UFSM 0027, another dinosaur femur from the same fossiliferous site (Müller et al., 2016). The distal end of the femur is expanded, but the fragmentary condition of the distal portion hinders any further observations on its structure.

Material. CAPPA/UFSM 0273. Distal articular surface of a right femur (Figure 7).

Diagnostic traits. The taxonomic assignation proposed here is tentative, given the fragmentary condition of the specimen, lacking clear synapomorphies of Dinosauria. The assignation relies, as such, on the similar morphology shared with CAPPA/UFSM 0028 (see below).

Description and remarks. This specimen is the most fragmentary of the sample. The preserved portion is 32.8 $\mathrm{mm}$ in length and the minimum circumference of the shaft is approximately $18 \mathrm{~mm}$. The maximum length of the distal articular surface is approximately $19.5 \mathrm{~mm}$. Regardless of the fragmentary condition, the size of the specimen is also smaller compared to the other dinosaur specimens from the same site, except CAPPA/UFSM 0028, a putative skeletally immature specimen of Pampadromaeus barberenai (Müller et al., 2019). Therefore, this specimen could belong to an immature individual. Indeed, there is an unusual deep groove on the distal articular surface, which resembles CAPPA/UFSM 0028. The cranial surface of the bone collapsed as a result of postmortem processes, creating a longitudinal sulcus, which is taphonomic in origin, the same possibly being the case for the concave cranial margin of the distal end. The popliteal fossa is well-developed proximodistally. However, the depression of this region also seems affected by postmortem processes. All three condyles are subequal in length, whereas Pampadromaeus barberenai (ULBRA-PVT016; CAPPA/ UFSM 0027) has a reduced crista tibiofibularis (Müller et al., 2016). This condition also differs from the condition in lagerpetids, where the crista tibiofibularis is remarkable expanded (Irmis et al., 2007; Nesbitt et al., 2009; Cabreira et al., 2016; Garcia et al., 2019).

\section{DISCUSSION AND CONCLUSION}

The morphology of the new specimens described here match those of coeval dinosaurs, especially non-herrerasaurid saurischians. Although the sizes of the recovered elements resemble those of Pampadromaeus barberenai, rather than Bagualosaurus agudoensis, a less-inclusive designation based 
on an apomorphic approach is difficult due to of the recent phylogenetic controversies concerning the earliest dinosaurs. For instance, the theropod/sauropodomorph split still is obscure in anatomical terms (Langer, 2014). In some analyses, putative basal members of Theropoda (e.g. Eodromaeus, Guaibasaurus, Daemonosaurus) are recovered as saurischians basal to this dichotomy (e.g. Cabreira et al., 2016; Pacheco et $a l ., 2019)$. Therefore, the synapomorphies of each dinosaur clade are, for now, poorly understood.

The new specimens, which represent five individuals, increase the number of dinosaurs collected from the Janner site, actually doubling the number of dinosaurs sampled from the locality. Yet, this content of dinosaurs is still low when compared to the record of cynodonts from the same locality. Taking solely the collection housed at CAPPA/UFSM until the end of 2019, the number of cynodonts from the Janner site is approximately five times higher than the total of dinosaurs (Table 1). Indeed, the paleofauna present at the Janner site (upper Hyperodapedon AZ/Exaeretodon sub-AZ - Müller \& Garcia, 2019) is consistent with the latest Carnian-earliest Norian records of the Ischigualasto Formation of Argentina (Exaeretodon biozone), where traversodontid cynodonts are the most abundant faunal element. Another quantification of the ecosystem parcel occupied by dinosaurs during the late Carnian indicates that dinosaurs correspond to $\sim 1.5 \%$ of the tetrapod record from the Ischigualasto Formation, Argentina (Martínez et al., 2013). Both quantifications agree that dinosaurs were rare components on the land ecosystems during the Carnian.

Therefore, it is not a surprise that some portions of the skeleton are yet unknown for the dinosaurs from the Janner site. For instance, the humerus (which is described here) is poorly preserved in Pampadromaeus barberenai and unknown in Bagualosarusus agudoensis. Moreover, the cervical series is completely unknown for both. Thus, the new specimens bring anatomical information that was, so far, unknown for the dinosaurs of the Janner site. Unfortunately, as previously mentioned, a less inclusive identification of the isolated elements is not possible at this time. Nevertheless, some comments are pertinent. For instance, the shape of the preserved cervical vertebrae does not match with that of Norian sauropodomorphs, like Macrocollum itaquii, which bears elongated vertebrae (Müller et al., 2018b). So, if the specimen CAPPA/UFSM 0270 belongs to one of the previously known dinosaurs from the Janner site, this dinosaur probably does not have an elongated neck, typical for a Carnian sauropodomorph. In addition, the preserved presacral vertebrae of this specimen are not craniocaudally short, as seen only in the cranialmost and caudalmost dorsal vertebrae of herrerasaurids among basal dinosauromorphs. Thus, the condition of CAPPA/UFSM 0270 is more similar to that of basal sauropodomorphs such as Buriolestes schultzi and Saturnalia tupiniquim. The presence of a trochanteric shelf in the described femora is also more related to the typical condition of Carnian dinosaurs, with the exception of Staurikosaurus pricei (Bittencourt \& Kellner, 2009; Garcia et al., 2019) or immature specimens (e.g. Marsola et al., 2018; Müller et al., 2019).

Regarding UFRGS-PV-1232-T, the overall morphology of the ilium and sacrum matches that of basal saurischians, such as Eodromaeus murphi Martinez et al., 2011, and early sauropodomorphs such as Buriolestes schultzi and Eoraptor lunensis Sereno et al., 1993. A peculiar feature of the ilium is the presence of rugosities related to muscle attachment scars. These rugosities have been used as a trait of saturnaliin sauropodomorphs (mainly Saturnalia tupiniquim and Chromogisaurus novasi), but a comparative study of basal dinosaurs ilia showed that this feature is more widespread among the group (Garcia et al., 2019). Indeed, other basal dinosaurs such as the holotype of Buriolestes schultzi and Herrerasaurus ischigualastensis, as well as non-dinosaurian dinosauriforms (e.g. Silesaurus opolensis, Ignotosaurus fragilis Martinez et al., 2013) also bear these rugosities. On the other hand, although widespread among basal dinosaurs, in sauropodomorphs these rugosities seem to be restricted to the basalmost forms, since they are absent in Pampadromaeus barberenai, Panphagia protos Martínez \& Alcober 2009, Bagualosaurus agudoensis, and Norian sauropodomorphs such as Macrocollum itaquii. Therefore, UFRGS-PV-1232-T has a condition similar to that of Carnian sauropodomorphs. Moreover, this specimen has a relatively craniocaudally short ilium, like Buriolestes schultzi (CAPPA/UFSM 00035) and Eoraptor lunensis (PVSJ 512), but slightly differing from the more elongated ilium of Saturnalia tupiniquim (MCP 3945-PV; MCP 3946-PV), Chromogisaurus novasi (PVSJ 845), and Panphagia protos (PVSJ 874), and also differing from the much more craniocaudally short ilium typical of herrerasaurids (e.g. Herrerasaurus ischigualastensis - PVSJ 373 and Staurikosaurus pricei - MCZ 1669). Nevertheless, several factors that may have influence in this feature (e.g. ontogeny) are still poorly understood in basal dinosaurs (Garcia et al., 2019).

Furthermore, the Janner site might represent a key window in deep time to a faunal turnover regarding major herbivores/omnivores in the Carnian land ecosystems. While deposits of the latest Ladinian-early Carnian include stenaulorhynchine rhynchosaurs (e.g. Brasinorhynchus Schultz, Langer \& Montefeltro, 2016) and traversodontid cynodonts (e.g. Massetognathus Romer, 1967) as major herbivores/ omnivores (Ezcurra et al., 2017; Schmitt et al., 2019), the mid to late Carnian ecosystems witnessed the rise and fall of the hyperodapedontine rhynchosaurs (e.g. Hyperodapedon), possibly to the benefit of traversodontid cynodonts (Langer et al., 2007), which become dominant on the latest Carnianearliest Norian (Martínez et al., 2013). Nonetheless, the latter are also virtually substituted by herbivorous/omnivorous dinosauromorphs (i.e. sauropodomorphs and silesaurids/ ornithischians - see Cabreira et al., 2016; Ezcurra et al., 2017; Garcia et al., 2019). Therefore, the specimens herein presented are an addition to the paleofauna of an important fossiliferous locality of the Late Triassic of southern Brazil, and expand the knowledge of some anatomical traits of the dinosaurs of this age. 
Table 1. Dinosaurs and cynodonts deposited at the CAPPA/UFSM collection.

\begin{tabular}{|c|c|c|c|}
\hline Specimen & Anatomical element & Taxonomic ascription & $\begin{array}{l}\text { Dinosauria (D) or } \\
\text { Cynodontia (C) }\end{array}$ \\
\hline CAPPA/UFSM 0027 & Femur & cf. Pampadromaeus barberenai & $\mathrm{D}$ \\
\hline CAPPA/UFSM 0028 & Femur & cf. Pampadromaeus barberenai & $\mathrm{D}$ \\
\hline CAPPA/UFSM 0029 & Skull and lower jaw & Trucidocynodon riograndensis & $\mathrm{C}$ \\
\hline CAPPA/UFSM 0030 & Skull and lower jaw & Exaeretodon & $\mathrm{C}$ \\
\hline CAPPA/UFSM 0030 & Skull and lower jaw & Exaeretodon & $\mathrm{C}$ \\
\hline CAPPA/UFSM 0030 & Skull and lower jaw & Exaeretodon & $\mathrm{C}$ \\
\hline CAPPA/UFSM 0030 & Lower jaw & Exaeretodon & $\mathrm{C}$ \\
\hline CAPPA/UFSM 0033 & Skull and lower jaw & Exaeretodon & $\mathrm{C}$ \\
\hline CAPPA/UFSM 0036 & Skull & Cynodontia & $\mathrm{C}$ \\
\hline CAPPA/UFSM 0199 & Femur & Cynodontia & $\mathrm{C}$ \\
\hline CAPPA/UFSM 0201 & Lower jaw & Traversodontidae & $\mathrm{C}$ \\
\hline CAPPA/UFSM 0202 & Lower jaw & Traversodontidae & $\mathrm{C}$ \\
\hline CAPPA/UFSM 0203 & Skull & Exaeretodon & $\mathrm{C}$ \\
\hline CAPPA/UFSM 0204 & Lower jaw & Exaeretodon & $\mathrm{C}$ \\
\hline CAPPA/UFSM 0205 & Lower jaw & cf. Exaeretodon & $\mathrm{C}$ \\
\hline CAPPA/UFSM 0208 & Lower jaw & Probainognathia & $\mathrm{C}$ \\
\hline CAPPA/UFSM 0215 & Canine tooth & cf. Exaeretodon & $\mathrm{C}$ \\
\hline CAPPA/UFSM 0216 & Maxilla & Exaeretodon & $\mathrm{C}$ \\
\hline CAPPA/UFSM 0217 & Post-canine tooth & Exaeretodon & $\mathrm{C}$ \\
\hline CAPPA/UFSM 0220 & Lower jaw & Exaeretodon & $\mathrm{C}$ \\
\hline CAPPA/UFSM 0222 & Skull & Exaeretodon & $\mathrm{C}$ \\
\hline CAPPA/UFSM 0223 & Humerus & cf. Traversodontidae & $\mathrm{C}$ \\
\hline CAPPA/UFSM 0231 & Lower jaw & Traversodontidae & $\mathrm{C}$ \\
\hline CAPPA/UFSM 0232 & Lower jaw & Traversodontidae & $\mathrm{C}$ \\
\hline CAPPA/UFSM 0235 & Lower jaw & Traversodontidae & $\mathrm{C}$ \\
\hline CAPPA/UFSM 0239 & Lower jaw & Traversodontidae & $\mathrm{C}$ \\
\hline CAPPA/UFSM 0243 & Partial skeleton & Traversodontidae & $\mathrm{C}$ \\
\hline CAPPA/UFSM 0250 & Autopodium & Cynodontia & $\mathrm{C}$ \\
\hline CAPPA/UFSM 0251 & Lower jaw & Exaeretodon & $\mathrm{C}$ \\
\hline CAPPA/UFSM 0263 & Lower jaw & Exaeretodon & $\mathrm{C}$ \\
\hline CAPPA/UFSM 0264 & Lower jaw & Exaeretodon & $\mathrm{C}$ \\
\hline CAPPA/UFSM 0265 & Lower jaw & Exaeretodon & $\mathrm{C}$ \\
\hline CAPPA/UFSM 0266 & Lower jaw & Exaeretodon & $\mathrm{C}$ \\
\hline CAPPA/UFSM 0267 & Lower jaw & Exaeretodon & $\mathrm{C}$ \\
\hline CAPPA/UFSM 0270 & Partial postcranium & cf. Saurischia & $\mathrm{D}$ \\
\hline CAPPA/UFSM 0271 & Humerus & Dinosauria & $\mathrm{D}$ \\
\hline CAPPA/UFSM 0272 & Femur & Dinosauria & $\mathrm{D}$ \\
\hline CAPPA/UFSM 0273 & Femur & cf. Dinosauria & $\mathrm{D}$ \\
\hline
\end{tabular}




\section{ACKNOWLEDGEMENTS}

We thank C.L. Schultz (curator of UFRGS), who made the specimen UFRGS-PV-1232-T available for study. We also extend our gratitude to J. Choiniere and A.B. Heckert for comments and suggestions that improved the quality of this manuscript.

\section{REFERENCES}

Alcober, O.A. \& Martinez, R.N. 2010. A new herrerasaurid (Dinosauria, Saurischia) from the Upper Triassic Ischigualasto formation of northwestern Argentina. ZooKeys, 63:55-81. doi:10.3897/zookeys. 63.550

Andreis, R.R.; Bossi, G.E. \& Montardo, D.K. 1980. O Grupo Rosário do Sul (Triássico) no Rio Grande do Sul, Brasil. In: CONGRESSO BRASILEIRO DE GEOLOGIA, 31, 1980. Anais, Camboriú, p. 659-673.

Apaldetti, C.; Pol, D. \& Yates, A. 2013. The postcranial anatomy of Coloradisaurus brevis (Dinosauria: Sauropodomorpha) from the Late Triassic of Argentina and its phylogenetic implications. Palaeontology, 56:277-301. doi:10.1111/j.14754983.2012.01198.x

Bittencourt, J.S. \& Kellner, A.W.A. 2009. The anatomy and phylogenetic position of the Triassic dinosaur Staurikosaurus pricei Colbert, 1970. Zootaxa, 2079:1-56. doi:10.11646/ zootaxa.2079.1.1

Cabreira, S.F.; Kellner, A.W.A.; Dias-da-Silva, S.; Roberto-da-Silva, L.; Bronzati, M.; Marsola, J.C.A.; Müller, R.T.; Bittencourt, J.S.; Batista, B.J.; Raugust, T.; Carrilho, R.; Brodt, A. \& Langer, M.C. 2016. A unique Late Triassic dinosauromorph assemblage reveals dinosaur ancestral anatomy and diet. Current Biology, 26:3090-3095. doi:10.1016/j.cub.2016.09.040

Cabreira, S.F.; Schultz, C.L.; Bittencourt, J.S.; Soares, M.B.; Fortier, D.C.; Silva, L.R. \& Langer, M.C. 2011. New stemsauropodomorph (Dinosauria, Saurischia) from the Triassic of Brazil. Naturwissenschaften, 98:1035-1040. doi:10.1007/ s00114-011-0858-0

Da-Rosa, A.A.S. 2015. Geological context of the dinosauriform bearing outcrops from the Triassic of Southern Brazil. Journal of South American Earth Sciences, 61:108-119. doi:10.1016/j. jsames.2014.10.008

Ezcurra, M.D. 2010. A new early dinosaur (Saurischia: Sauropodomorpha) from the Late Triassic of Argentina: a reassessment of dinosaur origin and phylogeny. Journal of Systematic Palaeontology, 8:371-425. doi:10.1080/14772019 .2010 .484650

Ezcurra, M.D.; Fiorelli, L.E.; Martinelli, A.G.; Rocher, S.; Baczko, M.B. von; Ezpeleta, M.; Taborda, J.R.A.; Hechenleitner, E.M.; Trotteyn, M.J. \& Desojo, J.B. 2017. Deep faunistic changes preceded the rise of dinosaurs in southwestern Pangaea. Nature Ecology \& Evolution, 1:1477-1483. doi:10.1038/s41559-0170305-5

Garcia, M.S.; Müller, R.T.; Da-Rosa, Á.A. \& Dias-da-Silva, S. 2019. The oldest known co-occurrence of dinosaurs and their closest relatives: a new lagerpetid from a Carnian (Upper Triassic) bed of Brazil with implications for dinosauromorph biostratigraphy, early diversification and biogeography. Journal of South American Earth Sciences, 91:302-319. doi:10.1016/j. jsames.2019.02.005
Griffin, C.T. \& Nesbitt, S.J. 2016. The femoral ontogeny and long bone histology of the Middle Triassic (?late Anisian) dinosauriform Asilisaurus kongwe and implications for the growth of early dinosaurs. Journal of Vertebrate Paleontology, 36:e1111224. doi:10.1080/02724634.2016.1111224

Horn, B.L.D.; Melo, T.P.; Schultz, C.L.; Philipp, R.P.; Kloss, H.P. \& Goldberg, K. 2014. A new third-order sequence stratigraphic framework applied to the Triassic of the Paraná Basin, Rio Grande do Sul, Brazil, based on structural, stratigraphic and paleontological data. Journal of South American Earth Sciences, 55:123-132. doi:10.1016/j.jsames.2014.07.007

Irmis, R.B.; Nesbitt, S.J.; Padian, K.; Smith, N.D.; Turner, A.H.; Woody, D. \& Downs, A. 2007. A Late Triassic dinosauromorph assemblage from New Mexico and the rise of dinosaurs. Science, 317:358-361. doi:10.1126/science. 1143325

Langer, M.C. 2003. The pelvic and hind limb anatomy of the stem sauropodomorph Saturnalia tupiniquim (Late Triassic, Brazil). PaleoBios, 23:1-40.

Langer, M.C. 2014. The origins of Dinosauria: much ado about nothing. Palaeontology, 57:469-478. doi:10.1111/pala.12108

Langer, M.C.; Abdala, F.; Richter, M. \& Benton, M.J. 1999. A sauropodomorph dinosaur from the Upper Triassic (Carnian) of southern Brazil. Comptes Rendus de l'Academie des Sciences Paris, 329:511-517. doi:10.1016/S1251-8050(00)80025-7

Langer, M.C.; McPhee, B.W.; Marsola, J.C.; Roberto-da-Silva, L. \& Cabreira, S.F. 2019. Anatomy of the dinosaur Pampadromaeus barberenai (Saurischia-Sauropodomorpha) from the Late Triassic Santa Maria Formation of southern Brazil. PloS ONE, 14:e212543. doi:10.1371/journal.pone.0212543

Langer, M.C.; Ramezani, J. \& Da Rosa, Á.A. 2018. U-Pb age constraints on dinosaur rise from south Brazil. Gondwana Research, 57:133-140. doi:10.1016/j.gr.2018.01.005

Langer, M.C.; Ribeiro, A.M.; Schultz, C.L. \& Ferigolo, J. 2007. The continental tetrapod-bearing Triassic of South Brazil. Bulletin of the New Mexico Museum of Natural History and Science, 41:201-218.

Liparini, A.; Oliveira, T.V.; Pretto, F.A.; Soares, M.B. \& Schultz, C.L. 2013. The lower jaw and dentition of the traversodontid Exaeretodon riograndensis Abdala, Barberena \& Dornelles, from the Brazilian Triassic (Santa Maria 2 Sequence, Hyperodapedon Assemblage Zone). Alcheringa, 37:331-337. doi:10.1080/031 15518.2013.752607

Marsola, J.C.; Bittencourt, J.S.; Butler, R.J.; Da Rosa, Á.A.; Sayão, J.M. \& Langer, M.C. 2018. A new dinosaur with theropod affinities from the Late Triassic Santa Maria Formation, South Brazil. Journal of Vertebrate Paleontology, 38:e1531878. doi: 10.1080/02724634.2018.1531878

Martínez, R.N.; Apaldetti, C.; Alcober, O.A.; Colombi, C.E.; Sereno, P.C.; Fernandez, E.; Malnis, P.S.; Correa, G.A. \& Abelin, D. 2013. Vertebrate succession in the Ischigualasto Formation. Journal of Vertebrate Paleontology, 32:10-30. doi:10.1080/0 2724634.2013.818546

Martinez, R.N.; Sereno, P.C.; Alcober, O.A.; Colombi, C.E.; Renne, P.R.; Montañez, I.P. \& Currie, B.S. 2011. A basal dinosaur from the dawn of the dinosaur era in southwestern Pangaea. Science, 331:206-210. doi:10.1126/science.1198467

Müller, R.T.; Araújo-Júnior, H.I.; Aires, A.S.S.; Silva Roberto-daSilva, L. \& Dias-da-Silva, S. 2015. Biogenic control on the origin of a vertebrate monotypic accumulation from the Late Triassic of southern Brazil. Geobios, 48:331-340. doi:10.1016/j. geobios.2015.05.001 
Müller, R.T.; Baczko, M.B.; Desojo, J.B. \& Nesbitt, S.J. 2020. The first ornithosuchid from Brazil and its macroevolutionary and phylogenetic implications for Late Triassic faunas in Gondwana. Acta Palaeontologica Polonica, 65:1-10. doi:10.4202/ app.00652.2019

Müller, R.T. \& Garcia, M.S. 2019. Rise of an empire: analysing the high diversity of the earliest sauropodomorph dinosaurs through distinct hypotheses. Historical Biology, in press. doi:10.1080/0 8912963.2019.1587754

Müller, R.T.; Langer, M.C.; Bronzati, M.; Pacheco, C.P.; Cabreira, S.F. \& Dias-Da-Silva, S. 2018a. Early evolution of sauropodomorphs: anatomy and phylogenetic relationships of a remarkably well preserved dinosaur from the Upper Triassic of southern Brazil. Zoological Journal of the Linnean Society, 184:1187-1248. doi:10.1093/zoolinnean/zly009

Müller, R.T.; Langer, M.C.; Cabreira, S.F. \& Dias-da-Silva, S. 2016. The femoral anatomy of Pampadromaeus barberenai based on a new specimen from the Upper Triassic of Brazil. Historical Biology, 28:656-665. doi:10.1080/08912963.2015.1004329

Müller, R.T.; Langer, M.C. \& Dias-da-Silva, S. 2018b. An exceptionally preserved association of complete dinosaur skeletons reveals the oldest long-necked sauropodomorphs. Biology letters, 14:20180633. doi:10.1098/rsbl.2018.0633

Müller, R.T.; Langer, M.C.; Pacheco, C.P. \& Dias-da-Silva, S. 2019. The role of ontogeny on character polarization in early dinosaurs: a new specimen from the Late Triassic of southern Brazil and its implications. Historical Biology, 31:794-805. doi:10.1080/ 08912963.2017.1395421

Nesbitt, S.J. 2011. The early evolution of archosaurs: relationships and the origin of major clades. Bulletin of the American Museum of Natural History, 352:1-292. doi:10.1206/352.1

Nesbitt, S.J.; Irmis, R.B.; Parker, W.G.; Smith, N.D.; Turner, A.H. \& Rowe, T. 2009. Hindlimb osteology and distribution of basal dinosauromorphs from the Late Triassic of North America. Journal of Vertebrate Paleontology, 29:498-516. doi:10.1671/039.029.0218

Nesbitt, S.J.; Sidor, C.A.; Irmis, R.B.; Angielczyk, K.D.; Smith, R.M.H. \& Tsuji, L.A. 2010. Ecologically distinct dinosaurian sister group shows early diversification of Ornithodira. Nature, 464:95-98. doi:10.1038/nature08718

Novas, F.E. 1993. New information on the systematics and postcranial skeleton of Herrerasaurus ischigualastensis (Theropoda: Herrerasauridae) from the Ischigualasto Formation (Upper Triassic) of Argentina. Journal of Vertebrate Paleontology, 13:400-423. doi:10.1080/02724634.1994.10011523

Novas, F.E. 1996. Dinosaur monophyly. Journal of Vertebrate Paleontology, 16:72-741. doi:10.1080/02724634.1996.1001 1361

Oliveira, T.V.; Schultz, C.L. \& Soares, M.B. 2007. O esqueleto pós craniano de Exaeretodon riograndensis Abdala et. al. (Cynodontia, Traversodontidae), Triássico do Brasil. Revista Brasileira de Paleontologia, 10:79-94. doi:10.4072/rbp.2007.2.02
Oliveira, T.V.; Soares, M.B. \& Schultz, C.L. 2010. Trucidocynodon riograndensis gen. nov. et sp. nov. (Eucynodontia), a new cynodont from the Brazilian Upper Triassic (Santa Maria Formation). Zootaxa, 2382:1-71. doi:10.11646/zootaxa.2382.1.1

Pacheco, C.; Müller, R.T.; Langer, M.; Pretto, F.A.; Kerber, L. \& da Silva, S.D. 2019. Gnathovorax cabreirai: a new early dinosaur and the origin and initial radiation of predatory dinosaurs. PeerJ, 7:e7963. doi:10.7717/peerj.7963

Piechowski, R.; Tałanda, M. \& Dzik, J. 2014. Skeletal variation and ontogeny of the Late Triassic Dinosauriform Silesaurus opolensis. Journal of Vertebrate Paleontology, 34:1383-1393. doi:10.1080/02724634.2014.873045

Pretto, F.A.; Langer, M.C. \& Schultz, C.L. 2019. A new dinosaur (Saurischia: Sauropodomorpha) from the Late Triassic of Brazil provides insights on the evolution of sauropodomorph body plan. Zoological Journal of the Linnean Society, 185:388-416. doi:10.1093/zoolinnean/zly028

Pretto, F.A.; Schultz, C.L. \& Langer, M.C. 2015. New dinosaur remains from the Late Triassic of southern Brazil (Candelária Sequence, Hyperodapedon Assemblage Zone). Alcheringa, 39:264-273. doi:10.1080/03115518.2015.994114

Schmitt, M.R.; Martinelli, A.G.; Melo, T.P. \& Soares, M.B. 2019. On the occurrence of the traversodontid Massetognathus ochagaviae (Synapsida, Cynodontia) in the early late Triassic Santacruzodon Assemblage Zone (Santa Maria Supersequence, southern Brazil): taxonomic and biostratigraphic implications. Journal of South American Earth Sciences, 93:36-50. doi:10.1016/j. jsames.2019.04.011

Sereno, P.C.; Forster, C.A.; Rogers, R.R. \& Monetta, A.M. 1993. Primitive dinosaur skeleton from Argentina and the early evolution of Dinosauria. Nature, 361:64-66. doi: 10.1038/361064a0

Stefanello, M.; Müller, R.T.; Kerber, L.; Martínez, R.N. \& Dias-DaSilva, S. 2018. Skull anatomy and phylogenetic assessment of a large specimen of Ecteniniidae (Eucynodontia: Probainognathia) from the Upper Triassic of southern Brazil. Zootaxa, 4457:351378. doi:10.11646/zootaxa.4457.3.1

Zerfass, H.; Lavina, E.L.; Schultz, C.L.; Garcia, A.J.V.; Faccini, U.F. \& Chemale, F. 2003. Sequence stratigraphy of continental Triassic strata of Southernmost Brazil: a contribution to Southwestern Gondwana palaeogeography and palaeoclimate. Sedimentary Geology, 161:85-105. doi:10.1016/S00370738(02)00397-4

Received in 16 March, 2020; accepted in 09 June, 2020. 